\title{
Effects of Zinc During Lactation on the Junctional Epithelium and Inserted Gum in Rats
}

\author{
Efectos del Zinc Durante la Lactancia sobre el Epitelio de Unión y la Encía Insertada en Ratas
}

\author{
Ana Luiza de Carvalho Felippini; Miguel Angel Sala; Ruberval Armando Lopes \& Gilberto André e Silva
}

FELIPPINI, A. L. C.; SALA, M. A.; LOPES, R. A. \& SILVA, G. E. Effects of zinc during lactation on the junctional epithelium and inserted gum in rats. Int. J. Morphol., 31(1):144-149, 2013.

SUMMARY: The purpose of this study was to evaluate the effects of zinc, during lactation, on the junctional epithelium and inserted gum of the first upper molar of rats. The study used one-day old male rats, divided into two groups: those whose mother had been treated with $300 \mathrm{mg}$ zinc chloride $\left(\mathrm{ZnCl}_{2}\right)$ in the drinker water (treated group), and those whose mothers did not receive $\mathrm{ZnCl}_{2}$ (control group). After 21 days, the rat pups were sacrificed. Using karyometrical techniques, the greater (D) and smaller (d) nuclear diameters of the different layers of the junctional and inserted gum epithelia were determined, and the mean geometric diameter, D/d ratio, perimeter, area, volume, volume/area ratio, eccentricity, shape coefficient, and the contour index were estimated. The 100-point Merz grid was used with the purpose of evaluating the citoplasmatic and celular volume, the nucleus/citoplasm relationship, number density, outer surface/ basal layer ratio, the thickness of epithelial layers, and the surface density. The results were submitted to statistical analysis using the Wilcoxon-Mann-Whitney test. The nuclei of the studied structures were significantly smaller, and the stereological results demonstrated that there were smaller cells, hence meaning a greater number of cells per $\mathrm{mm}^{3}$ of tissue, in the treated group. Zinc caused changes on the studied epitheliums, according to morphometric and stereological evaluations.

KEY WORDS: Zinc; Lactation; Junctional epithelium; Inserted gum.

\section{INTRODUCTION}

There has been a significant decrease in the use of metallic materials over the last years, because of the growing search for esthetic materials. However, metal is still used to produce copings and metal-ceramic restoration substructures commonly employed in fixed partial dentures (Wataha \& Messer, 2004). The metal structures of removable partial dentures are still cast using metals, thus zinc may also be present in implants and implant-supported dentures (Shimpo, 2007; Xu et al., 2007).

Zinc is present in various metal alloys used in dentistry. Knowing the metals comprising the alloy is essential in order to preserve the patients' health, because metal alloys can be in contact with mouth tissues for a long period of time as they are present in extensive oral rehabilitations (Rinic et al., 2003; Celebic et al., 2006; House et al., 2008). Therefore, every material used to produce metal alloys must comply with rigorous safety and efficacy standards.

The moist environment of the mouth is a suitable background for corrosion, as it promotes favorable electrochemical conditions (Celebic et al.; Faccioni et al., 2003). The released metals can penetrate the tissues of the mouth, reach the gastrointestinal tract through saliva, and be absorbed by the intestines or reach the whole body carried by the lymph and blood (Rinic et al.; Faccioni et al.; Biego et al., 1998; Ferreira et al., 2003). The metal ions released in the mouth may cause local toxic reactions, or be transferred to distant organs, causing some type of systemic toxicity (Rinic et al.).

The presence of high concentrations of metals or toxic metal micro-pollutants, even at low concentrations, in human breast milk may cause cellular changes and clinical manifestations in newborns. The effects from the metal depend on the level and length of the exposure (Rossipal \& Krachler, 1998). Zinc concentrations increase from the colostrum to the matured milk. A more extensive intestinal absorption would lead to an increased bioavailability of the mineral element to the mammary gland, affecting its concentration in the breast milk (Manaranche \& Hornberger, 2005). 
It has been reported that cellular vitality diminishes in cultures of gingival tissue cells that have been exposed to metal ions (Catelas et al., 2003). Other studies show that metal ions penetrate the plasma membrane of cells, bond to cellular enzymes and modulate the expression of cytokines, mediating local adverse responses and remote tissue responses (Catelas et al., 2005; Petit et al., 2006).

The analysis of adverse biological effects depends considerably on the employed methodology (Catelas et al., 2003). Tests in vitro can be performed using several types of cell cultures (Schmalz et al., 2000; Petit et al., 2006). Animal tests allow the occurrence of complex interactions between the metal and biological systems with broader biological responses. The main disadvantages of animal tests are that they may be more difficult to interpret and control, and, in some cases, they can be costly.

Therefore, the objective of the present study was to evaluate the effects of zinc, during lactation, on the junctional epithelium and inserted gum in rats.

\section{MATERIAL AND METHOD}

One-day old male Wistar rats (Rattus norvegicus) were used divided into two groups: treated group (T): five pups randomly chosen from litters of 10 lactating females, who received $300 \mathrm{mg}$ zinc chloride per liter of distilled water in the drinker during lactation; and control group (C): five pups, also chosen at random, whose mothers received pure water in the drinker during lactation.

After the experimental period (21 days) the pups were sacrificed with an overdose of anesthesia (Tribromoethanol (2,2,2 - Tribromoethanol, Aldrich). The heads were separated from the bodies, and immediately immersed in a fixating solution, containing alcohol at $80 \%-85 \mathrm{ml}$, formalin -10 $\mathrm{ml}$, and acetic acid $-5 \mathrm{ml}$, for $24 \mathrm{~h}$ at room temperature. The material was then immersed in a solution of sodium citrate $20 \%$ and formic acid $30 \%$ in equal parts for decalcification. After fixation and dehydration, the heads were disarticulated and the palate was sectioned in frontal planes, at the level of the first molars. After embedded in paraffin, serial $6 \mu \mathrm{m}$ thick sections were made, with an interval of 10 sections, and stained with hematoxylin and eosin.

With the purpose of making a quantitative evaluation of the cellular changes that occur to the junctional epithelium and inserted gum in rats, proper karyometric and stereological techniques were used.
The following nuclear parameters were estimated for the studied tissues using karyometric techniques: greater diameter (D), smaller diameter (d), mean geometrical diameter; relationship between the greater and smaller diameters $(\mathrm{D} / \mathrm{d})$; perimeter $(\mathrm{P})$; area: $(\mathrm{A})$; volume $(\mathrm{V})$; volume to area ratio (V/A); shape coefficient; contour index and eccentricity (Sala et al., 1994).

The stereological analysis was performed using the grid idealized by Merz (1968), and estimated the following parameters: cytoplasm volume, cell volume, nucleus/ cytoplasm (N/C) ratio, number density, epithelial layer thickness and surface density (Sala et al., 1992). The obtained data were statistically confronted using the Wilcoxon - Mann - Whitney nonparametric test.

\section{RESULTS}

The karyometry of the cells from the basal layer of the junctional epithelium revealed that the diameters, perimeter, area, volume, and the volume/area ratio were significantly smaller in pups of the treated group than in the control ones, but there were no significant differences between the studied groups regarding the parameters that evaluated the nuclear shape (D/d ratio, eccentricity, shape coefficient, and contour index). The karyometry of the cells of the spinous layer of the junctional epithelium evinced that the nuclear size, evaluated by the diameters, perimeter, area, volume, and volume/area ratio, was significantly smaller in the treated group animals compared to the control ones, while the nuclear shape did not show significant differences between the groups for the cells of the spinous layer of the junctional epithelium (Table I).

The karyometric study of cells of the basal layer of the inserted gum epithelium revealed that the diameters, perimeter, area, volume and volume/area ratio were significantly smaller in animals treated with zinc compared to controls, while the nuclear shapes did not show any significant differences between the animals in the treated and control groups. The results corresponding to the mean karyometric values estimated in the nuclei of the spinous layer of the inserted gum of pups of the treated and control animals are shown in Table II. It can be observed that the size of the nuclei of the spinous layer of the inserted gum epithelium was significantly reduced in the treated group $(\mathrm{p}$ $<0.01$ ). The nuclei shape in the treated group showed a significant difference only for eccentricity, whereas the other parameters did not show any significant differences between groups. According to the evaluated karyometric parameters, the cells of the granular layer of the inserted gum epithelium 
Table I. Mean karyometric values of the nuclei of basal and spinous layer cells of the junctional epithelium of the first upper molar in rats from the control group (C) and treated group (T). Wilcoxon-Mann-Whitney test.

\begin{tabular}{lcccc}
\hline \multirow{2}{*}{ Parameter } & \multicolumn{2}{c}{ Basal Layer } & \multicolumn{2}{c}{ Spinous Layer } \\
\cline { 2 - 5 } & $\mathbf{C}$ & $\mathbf{T}$ & $\mathbf{C}$ & $\mathbf{T}$ \\
\hline Greater diameter $(\mu \mathrm{m})$ & 8.14 & $6.16^{*}$ & 8.37 & $6.52^{*}$ \\
Smaller diameter $(\mu \mathrm{m})$ & 6.12 & $4.56^{*}$ & 5.95 & $4.57^{*}$ \\
Mean diameter $(\mu \mathrm{m})$ & 7.05 & $5.29^{*}$ & 7.05 & $5.45^{*}$ \\
D/d ratio & 1.34 & 1.39 & 1.43 & 1.49 \\
Perimeter $(\mu \mathrm{m})$ & 22.55 & $17.01^{*}$ & 33.71 & $17.46^{*}$ \\
Area $\left(\mu \mathrm{m}^{2}\right)$ & 39.34 & $22.19^{*}$ & 39.36 & $22.99^{*}$ \\
Volume $\left(\mu \mathrm{m}^{3}\right)$ & 188.63 & $80.58^{*}$ & 189.69 & $84.74^{*}$ \\
V/A ratio & 4.69 & $3.51^{*}$ & 4.68 & $3.57^{*}$ \\
Eccentricity & 0.60 & 0.57 & 0.64 & 0.68 \\
Shape Coefficient & 0.96 & 0.95 & 0.94 & 0.93 \\
Contour Index & 3.61 & 3.64 & 3.65 & 3.66 \\
\hline
\end{tabular}

$* \mathrm{p}<0.01$

in the treated group have smaller nuclei, whereas the nuclear shape did not reveal any significant differences between groups (Table II).

The stereological analysis of the basal layer of the junctional epithelium showed that the cellular and cytoplasm volumes, as well as the N/C ratio were significantly smaller in the treated group. Moreover, the thickness of the basal layer revealed a significant reduction whereas the numerical cell density was significantly higher in the treated group than in control animals. The spinous layer of the junctional epithelium had significant differences for all the estimated stereological parameters. It was observed there was a significant reduction in cellular and cytoplasm volume, N/C ratio and thickness in the treated group, whereas the number density was greater in the treated group than in the control one (Table III).

The stereological study of the basal layer of the inserted gum epithelium did not show any statistically significant differences between the studied groups for cell volume, cytoplasm volume and cell number density. The stereological analysis of the spinous layer of the inserted gum epithelium showed a significant reduction in cell and cytoplasm volumes, N/C ratio and cellular layer thickness in the treated group, whereas the number density was significantly greater in this group. In the granular layer of the inserted gum epithelium there were no significant differences between groups for cell and cytoplasm volumes, thickness and number density, but a significant reduction of the N/C ratio was observed in the treated group (Table IV).

The thickness of the junctional epithelium was significantly smaller, although the number density was greater in treated animals than in control ones (Table V). There were no significant differences between groups for surface density and the outer surface/basal surface ratio. The thickness of the inserted gum epithelium was smaller in the treated animals than in the control group. Surface and number density, on the other hand, were significantly greater in the treated group. The outer surface/basal surface ratio, however, showed no statistical differences between the groups (Table V).

Table II. Mean karyometric values of the nuclei of basal, spinous and granular layer cells of the inserted gum epithelium of the first upper molar in rats from the control group (C) and treated group (T). Wilcoxon-MannWhitney test.

\begin{tabular}{lcccccc}
\hline \multirow{2}{*}{ Parameter } & \multicolumn{2}{c}{ Basal Layer } & \multicolumn{2}{c}{ Spinous Layer } & \multicolumn{2}{c}{ Granular Layer } \\
\cline { 2 - 6 } & $\mathbf{C}$ & $\mathbf{T}$ & $\mathbf{C}$ & $\mathbf{T}$ & $\mathbf{C}$ & $\mathbf{T}$ \\
\hline Greater diameter $(\mu \mathrm{m})$ & 8.84 & $7.32^{*}$ & 8.24 & $6.99^{* *}$ & 9.03 & $6.60^{* *}$ \\
Smaller diameter $(\mu \mathrm{m})$ & 6.27 & $5.36^{*}$ & 6.02 & $4.86^{* *}$ & 6.83 & $5.24^{* *}$ \\
Mean diameter $(\mu \mathrm{m})$ & 7.42 & $6.26^{* *}$ & 7.03 & $5.76^{* *}$ & 7.84 & $5.87^{* *}$ \\
D/d ratio & 1.44 & 1.38 & 1.39 & 1.75 & 1.34 & 1.26 \\
Perimeter $(\mu \mathrm{m})$ & 23.97 & $20.09^{* *}$ & 22.61 & $18.83^{* *}$ & 25.08 & $18.76^{* *}$ \\
Area $\left(\mu \mathrm{m}^{2}\right)$ & 43.58 & $31.03^{* *}$ & 39.52 & $26.94^{* *}$ & 48.74 & $27.89^{* *}$ \\
Volume $\left(\mu \mathrm{m}^{3)}\right.$ & 220.08 & $132.81^{* *}$ & 194.57 & $108.53^{* *}$ & 168.47 & $113.69^{* *}$ \\
V/A ratio & 4.93 & $4.16^{* *}$ & 4.67 & $3.86^{* *}$ & 5.21 & $3.94 * *$ \\
Eccentricity & 0.63 & 0.37 & 0.60 & 0.64 & 0.57 & $0.50^{*}$ \\
Shape Coefficient & 0.94 & 0.95 & 0.95 & 0.93 & 0.96 & 0.97 \\
Contour Index & 3.65 & 3.63 & 3.63 & 3.66 & 3.62 & 3.59 \\
\hline
\end{tabular}


Table III. Mean values of cytoplasm volume, cell volume, nucleus/cytoplasm ratio, thickness, and number density of cells from the basal and spinous layers of the junctional epithelium of the first upper molar in rats from the control group (C) and treated group (T). Wilcoxon-MannWhitney test.

\begin{tabular}{lcccc}
\hline \multirow{2}{*}{ Parameters } & \multicolumn{2}{c}{ Basal Layer } & \multicolumn{2}{c}{ Spinous Layer } \\
\cline { 2 - 5 } & C & T & C & T \\
\hline Cytoplasm Volume $\left(\mu \mathrm{m}^{3}\right)$ & 135.73 & $54.82^{* *}$ & 210.85 & $87.64 * *$ \\
Cell Volume $\left(\mu \mathrm{m}^{3}\right)$ & 288.73 & $113.88^{* *}$ & 389.06 & $146.70^{* *}$ \\
N/C Ratio & 0.35 & $0.22 *$ & 0.20 & $0.15^{* *}$ \\
Thickness $(\mu \mathrm{m})$ & 11.29 & $6.87 * *$ & 27.59 & $15.94 * *$ \\
Number Density $\left(\mathrm{Nx} 106 / \mathrm{mm}^{3}\right)$ & 3.60 & $9.50^{* *}$ & 2.76 & $7.42^{* *}$ \\
\hline$* p<0.05 * * * p<0.01$ & & & &
\end{tabular}

Table IV. Mean values of cytoplasm volume, cell volume, nucleus/cytoplasm ratio, thickness, and number density of cells from the basal, spinous, and granular layers of the inserted gum epithelium of the first upper molar in rats from the control (C) and treated groups (T). Wilcoxon-Mann-Whitney test.

\begin{tabular}{lcccccc}
\hline \multirow{2}{*}{ Parameter } & \multicolumn{2}{c}{ Basal Layer } & \multicolumn{2}{c}{ Spinous Layer } & \multicolumn{2}{c}{ Granular Layer } \\
\cline { 2 - 7 } & $\mathbf{C}$ & $\mathbf{T}$ & $\mathbf{C}$ & $\mathbf{T}$ & \multicolumn{1}{c}{ C } & T \\
\hline Cytoplasm Volume $\left(\mu \mathrm{m}^{3}\right)$ & 122.55 & 385.06 & 362.34 & $129.15^{*}$ & 512.68 & 238.84 \\
Cell Volume $\left(\mu \mathrm{m}^{3}\right)$ & 302.14 & 501.92 & 577.33 & $213.66^{*}$ & 478.97 & 323.35 \\
N/C Ratio & 0.36 & $0.19 *$ & 0.19 & 0.16 & 0.20 & $0.11^{*}$ \\
Thickness $(\mu \mathrm{m})$ & 10.40 & $7.33^{*}$ & 44.03 & $29.28^{*}$ & 12.71 & 17.46 \\
Number Density $\left(\mathrm{Nx} 106 / \mathrm{mm}^{3}\right)$ & 3.40 & 4.06 & 1.78 & $4.92^{*}$ & 2.48 & 3.32 \\
\hline
\end{tabular}

$* \mathrm{p}<0.01$

Table V. Mean values of density of surface, total thickness, outer surface/basal layer ratio, and cell number density of the junctional epithelium and inserted gum epithelium of the first upper molar in rats from the control (C) and treated groups (T). Wilcoxon-Mann-Whitney test.

\begin{tabular}{lcccc}
\hline \multirow{2}{*}{ Parameter } & \multicolumn{2}{c}{ Junctional epithelium } & \multicolumn{2}{c}{ Inserted gum epithelium } \\
\cline { 2 - 5 } & $\mathbf{C}$ & $\mathbf{T}$ & $\mathbf{C}$ & $\mathbf{T}$ \\
\hline Surface Density $\left(\mathrm{mm}^{2} / \mathrm{mm}^{3}\right)$ & 2.42 & 3.12 & 1.04 & $1.57^{*}$ \\
Total Thickness $(\mu \mathrm{m})$ & 34.05 & $28.21^{* *}$ & 131.68 & $58.02^{*}$ \\
Outer surface/Basal Layer Ratio & 0.85 & 0.75 & 0.71 & 0.78 \\
Number Density $\left(\mathrm{Nx} 106 / \mathrm{mm}^{3}\right)$ & 2.94 & $8.10^{* *}$ & 2.02 & $4.76^{* *}$ \\
\hline
\end{tabular}

$* \mathrm{p}<0.05 ; * \mathrm{p}<0.01$

\section{DISCUSSION}

Not all the evaluated parameters showed significant differences between the control and treated groups; however, all the observed changes indicate a hazardous action of the metal, causing a disorganization of the gingival tissues.

Cytotoxic substances affect the structures of cells and organelles. Metals can reduce the number and size of mitochondria, change the form of the nuclei, and reduce intracellular ATP and RNA and protein synthesis. Human gingival fibroblasts exposed to metal alloys suffered structure form changes. Three mechanisms have been suggested as being the responsible for the toxicity of metal ions: blocking groups of biomolecules with essential functions; displacing essential ions from their respective biomolecules and changing the active confirmation of the biomolecules (Messer et al., 1999).

The disorder in cell physiology occurs when exogenous metals bond to the proteins or displace 
physiological metals from their natural transporters causing structural and/or functional damages in the bonding agents. The oxidative hazards can be involved in the induction of the toxicity and cellular changes by zinc seen in this study. Some metals change the metabolism of calcium, iron and copper, in addition to inhibiting those antioxidants and interfering in the mechanisms of DNA repair and replication (Bonda et al., 2001; Kasprzak, 2002). The DNA molecule, abundant in phosphate anions and oxygen-donating groups, becomes a site favorable for cation bonding, which would explain the presence of metals in the nuclei when cell cultures are exposed to the metals in vitro (Kasprzak).

Metal particles have the power to produce reactive oxygen species and thus cause irreversible biochemical hazards such as lipid peroxidation, protein oxidation, and oxidation of major DNA components with consequent tissue hazards. Protein oxidation is highly pathogenic, causing deleterious effects in protein function. Proteins bonded to metals can promote the oxidation of neighboring macromolecules (Petit et al., 2005).

Metal ions can induce several levels of toxicity in gingival fibroblasts in humans. Different cell types can suffer diverse types of toxicity. Metals are capable of inducing cellular death by necrosis and apoptosis, inhibit the action of several enzymes, and reduce the DNA and RNA synthesis (Issa et al., 2008).

It was concluded that zinc, during lactation, affected the normal development of the junctional epithelium and inserted gum in rats. The observed changes denote the hazardous action of the metal. The present study did not elucidate all aspects of the role played by the metal in the development of mouth structures, but opened perspectives for further studies to be performed with the purpose of finding the mechanisms through which zinc caused the referred toxicity.

FELIPPINI, A. L. C.; SALA, M. A.; LOPES, R. A. \& SILVA, G. E. Efectos del zinc durante la lactancia sobre el epitelio de unión y la encía insertada en ratas. Int. J. Morphol., 31(1):144-149, 2013.

RESUMEN: El objetivo de este estudio fue evaluar los efectos del zinc durante la lactancia, sobre el epitelio de unión y la encía insertada del primer molar superior de ratas. Fueron utilizadas ratas macho de un día de edad, divididas en dos grupos: aquellas cuyas madres habían sido tratadas con $300 \mathrm{mg}$ de cloruro de zinc $\left(\mathrm{ZnCl}_{2}\right)$ con agua del bebedero (grupo tratado) y aquellas cuyas madres no recibieron $\mathrm{ZnCl}_{2}$ (grupo control). Las crías fueron sacrificadas después de 21 días. Utilizando técnicas cariométricas fueron medidos los diámetros mayor (D) y menor (d) de los núcleos de las células de los diferentes estratos del epitelio de unión y de la encía insertada, estimándose el diámetro geométrico medio, la relación D/d, perímetro, área, volumen, relación volumen/área, excentricidad, coeficiente de forma e índice de contorno. Fue usada la rejilla de Merz, de 100 puntos, con la finalidad de evaluar el volumen celular y citoplasmático, la relación núcleo/citoplasma, densidad numérica, relación superficie externa/superficie basal, espesor de las capas epiteliales y densidad de superficie. Los resultados fueron sometidos a análisis estadístico mediante el test de Wilcoxon-Mann-Whitney. En el grupo tratado los núcleos celulares de las estructuras estudiadas fueron significativamente menores y los resultados estereológicos demostraron que las células eran menores, por lo tanto, con mayor número por $\mathrm{mm}^{3}$ de tejido. De acuerdo a los resultados morfométricos y estereológicos, el zinc provocó cambios en los epitelios estudiados.

PALABRAS CLAVE: Zinc; Lactancia; Epitelio de unión; Encía insertada.

\section{REFERENCES}

Biego, G. H.; Joyeux, M.; Hartemann, P. \& Debry, G. Determination of mineral contents in different kinds of milk and estimation of dietary intake in infants. Food Addit. Contam., 15(7):775-81, 1998.

Bonda, P. L .F.; Porrini, R.; Rizzio, E.; Pietra, R.; Fortaner, S. \& Sabbioni, E. Trace metals in oral mucosa in relation to the lichen ruberplanus pathology. A preliminary study carried out by neutron activation analysis. J. Trace Elem. Med. Biol., 15(23):79-83, 2001.

Catelas, I.; Petit, A.; Vali, H.; Fragiskatos, C.; Meilleur, R.; Zukor, D. J.; et al. Quantitative analysis of macrophage apoptosis vs. necrosis induced by cobalt and chromium ions in vitro. Biomaterials, 26(15):2441-53, 2005.
Catelas, I.; Petit, A.; Zukor, D.J.; Antoniou, J. \& Huk, O. L. TNFa secretion and macrophage mortality induced by cobalt and chromium ions in vitro - Qualitative analysis of apoptosis. Biomaterials, 24(3):383-91, 2003.

Celebic, A.; Baucic, M.; Stipetic, J.; Baucic, I.; Miko, S. \& Momcilovic, B. Ion release from gold/platinum dental alloy: could release of other elements be accountable in the contact allergy attributed to the gold? J. Mat. Sci. Mat.Med., 17(4):301$5,2006$.

Faccioni, F.; Franceschetti, P.; Cerpelloni, M. \& Fracasso, M. E. In vivo study on metal release from fixed orthodontic appliances and DNA damage in oral mucosa cells. Am. J. Orthod. Dentofacial Orthop., 124(6):687-93, 2003. 
Ferreira, M. E.; de Lourdes Pereira, M.; Garcia e Costa, F.; Sousa, J. P. \& de Carvalho, G. S. Comparative study of metallic biomaterials toxicity: a histochemical and immunohistochemical demonstration in mouse spleen. J. Trace Elem. Med. Biol., 17(1):45-9, 2003.

House, K.; Sernetz, F.; Dymock, D.; Sandy, J. R. \& Ireland, A. J. Corrosion of orthodontic appliances-should we care? Am. J. Orthod. Dentofacial Orthop., 133(4):584-92, 2008.

Issa, Y.; Brunton, P.; Waters, C. M. \& Watts, D. C. Cytotoxicity of metal ions to human oligodendroglial cells and human gingival fibroblasts assessed by mitochondrial dehydrogenase activity. Dent. Mater., 24(2):281-7, 2008.

Kasprzak, S. K. Oxidative DNA and protein damage in metalinduced toxicity and carcinogenesis. Free Radic. Biol. Med., 32(10):958-67, 2002.

Manaranche, C. \& Hornberger, H. Corrosion and biocompatibility of dental alloys. Eur. Cell Mater., 9(Suppl. 1):35-6, 2005.

Merz, W. A. Die Streckenmessung an gerichteten Strukturen in Mikroskop und ihre Anwendung zur Bestimmung von Oberflãchen-volumen-relationen in Knochenewebe. Mikroskopie, 22(5):132-42, 1968.

Messer, R. L.; Bishop, S. \& Lucas, L. C. Effects of metallic ion toxicity on human gingival fibroblasts morphology. Biomaterials, 20(18):1647-57, 1999.

Petit, A.; Mwale, F.; Tkaczyk, C.; Antoniou, J.; Zukor, D. J. \& Huk, O. L. Cobalt and chromium ions induce nitration of proteins in human U937 macrophages in vitro. J. Biomed. Mater. Res. A, 79(3):599-605, 2006.

Petit, A.; Mwale, F.; Tkaczyk, C.; Antoniou, J.; Zukor, D. J. \& Huk, O. L. Induction of protein oxidation by cobalt and chromium ions in human U937 macrophages. Biomaterials, 26(21):4416-22, 2005.

Rinic, N.; Baucic, I.; Miko, S.; Papic, M. \& Prohic, E. Corrosion behaviour of the Co-Cr-Mo dental alloy in solutions of different composition and different $\mathrm{pH}$ values. Coll. Antropol., 27(Suppl. 2):99-106, 2003.
Rossipal, E. \& Krachler, M. Pattern of trace elements in human milk during the course of lactation. Nutr. Res., 18(1):11-24, 1998.

Sala, M. A.; Komesu, M. C.; Lopes, R. A. \& Maia Campos, G. Karyometric study of basal cell carcinoma. Braz. Dent. J., $5(1): 11-4,1994$

Sala, M. A.; Lopes, R. A. \& Matheus, M. Método morfológico para análisis cuantitativa de los tejidos. Determinación de los parámetros normales para el hepatocito de rata. Arch. Fac. Med. Zaragoza, 32:29-31, 1992.

Schmalz, G.; Schweikl, H. \& Hiller, K. A. Release of prostaglandin E2, IL-6 and IL-8 from human oral epithelial culture models after exposure to compounds of dental materials. Eur. J. Oral Sci., 108(5):442-8, 2000.

Shimpo, H. Effect of arm design and chemical polishing on retentive force of cast titanium alloy clasps. J. Prosthod., 17(4):300-7, 2007.

Wataha, J. C. \& Messer, R. L. Casting alloys. Dent. Clin. North Am., 48(2):vii-viii, 499-512, 2004.

Xu, L.; Yu, G.; Zhang, E.; Pan, F. \& Yang, K. In vivo corrosion behavior of $\mathrm{Mg}-\mathrm{Mn}-\mathrm{Zn}$ alloy for bone implant application. $J$. Biomed. Mater. Res. A, 83(3):703-11, 2007.

Correspondence to:

Ana Luiza de Carvalho Felippini

Department of Morphology, Stomatology and Physiology

University of São Paulo - Faculty of Dentistry of Ribeirão

Preto

Avenida do Café, s/n

Campus Universitário - CEP 14040-904

Ribeirão Preto - São Paulo

BRAZIL.

E-mail: anafelippini@hotmail.com.br

Received: 20-05-2012

Accepted: 10-12-2012 